\title{
FACE-ing the challenges of increasing surface ozone concentration in Asia
}

\author{
Kazuhiko KOBAYASHI ${ }^{\text {a, }}$ \\ ( ${ }^{a}$ The University of Tokyo 1-1-1, Yayoi, Bunkyo-ku, Tokyo, 113-8657 Japan)
}

\section{Rise of surface ozone concentration and its impacts on vegetation.}

Human activities are changing the Earth's atmosphere, and thereby exerting influences on land vegetation including crops and forests. Ozone $\left(\mathrm{O}_{3}\right)$ near the ground surface is a product of airphase reactions which involve nitrogen oxides, hydrocarbons, and carbon monoxide (CO) (The Royal Society 2008). Its concentration has risen since the preindustrial times throughout the northern hemisphere, and often reaches the levels damaging to vegetation across wide areas (Mills et al., 2011). The rise of surface $\mathrm{O}_{3}$ concentration $\left(\left[\mathrm{O}_{3}\right]\right)$ is particularly rapid in industrializing countries of Asia, such as China, where the $\mathrm{O}_{3}$ damages to vegetation have become prevalent (Feng et al. 2014). The $\left[\mathrm{O}_{3}\right]$ in the troposphere will keep rising in the developing world for the coming decades (The Royal Society 2008), and therefore the damages to agricultural crops and forest trees could become more serious than they are now.

For some, the rising surface $\left[\mathrm{O}_{3}\right]$ might sound a new threat, but it was in fact more than 50 years ago when $\mathrm{O}_{3}$ was first identified as the agent causing injuries in agricultural crops (Richards et al., 1958; Heggestad 1959) and forest trees (Karnosky et al., 2007). Since then, a very large number of studies have been conducted for the effects of $\mathrm{O}_{3}$ on vegetation mostly in North America and Europe. Feng and Kobayashi (2009), for example, collected 406 observations on 6 major crop species published in 87 articles for the meta-analysis of the growth and yield responses to $\mathrm{O}_{3}$. Many literature reviews are available, e.g. Ashmore (2005) and Karnosky et al. (2007). In Japan, Matsuoka et al. (1976) first identified $\mathrm{O}_{3}$ as the main cause of the foliar injury in rice, whereas they noted that the visible damages had been observed in field crops by around 1969. Many studies followed the early studies and reported negative impacts of $\mathrm{O}_{3}$ on plants in Japan as reviewed by Kobayashi (1999).

\section{Development of apparatus for exposing plants to elevated ozone concentrations.}

Once the prevalence of the $\mathrm{O}_{3}$ damages to plants was recognized, research efforts followed two directions: one direction was to better understand the mechanisms of the $\mathrm{O}_{3}$ damages, and the other was to quantify the $\mathrm{O}_{3}$ impacts on vegetation in the realworld. Either direction of studies needed development of experimental apparatus. The better understandings of the mechanisms were facilitated by the environmentally-controlled plant growth chambers, in which the $\left[\mathrm{O}_{3}\right]$ was maintained at the desired level precisely along with other environmental variables. To work on the mechanisms at a whole plant scale, sun-lit plant growth cham-

\footnotetext{
†Corresponding Author: aclasman@mail.ecc.u-tokyo.ac.jp

DOI: 10.2480/agrmet.D-15-00100
}

bers were popular (Fig. 1), whereas artificially-lit chambers were often used to work at a leaf or smaller scale mechanisms. These chambers are still useful for the mechanism studies.

It was, however, recognized that they needed different types of experimental apparatus for achieving the other goal: realistic quantification of the $\mathrm{O}_{3}$ impacts on plants. The open-top field chamber (Fig. 2) has been most widely used for this purpose since its development in early 1970s (Heagle et al., 1973). With the ceiling of the small greenhouse being removed, the climate in the chamber is partly connected with that outside unlike the closed chambers (Fig. 1). Ozone concentrations in the chamber are maintained at more-than-one levels above the ambient level with the controlled addition of artificially-generated $\mathrm{O}_{3}$ to the air blown into the chamber. In addition, charcoal filtering of the blown air allows a sub-ambient level of $\left[\mathrm{O}_{3}\right]$ in the chamber. Temporal fluctuations in the ambient $\left[\mathrm{O}_{3}\right]$ are partly retained in the chambers representing a more realistic $\left[\mathrm{O}_{3}\right]$ regime than the fixed timecourse of $\left[\mathrm{O}_{3}\right]$ in environmentally-controlled chambers. Plants grown in the chamber have the rhizosphere intact in the field soil. With these features, i.e. multi-level $\left[\mathrm{O}_{3}\right]$ and the quasi-realistic growing environment, the open-top chamber has greatly facilitated the establishment of the quantitative relationships between the extent of $\mathrm{O}_{3}$ pollution (dose) and the effects on plant performances (response). Thus established dose-response relationships (e.g. Mills et al, 2007) have been widely used to quantify the $\mathrm{O}_{3}$ impacts on vegetation at present and in the future (e.g. Avnery et al., 2011a, b).

Despite the similarities of the environment in the open-top chamber to that in the real-world field, however, it has been recognized from the outset that the plant growth and $\mathrm{O}_{3}$ damages in the chamber are different from those in the field outside (Heagle

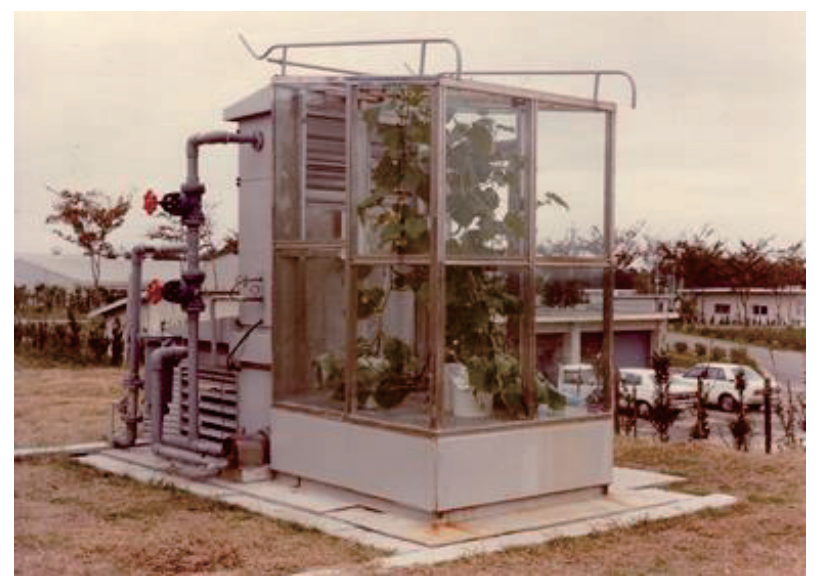

Fig. 1. A sun-lit glass chamber for exposing vegetable crops to controlled concentrations of ozone in Tsu, Mie, Japan. 


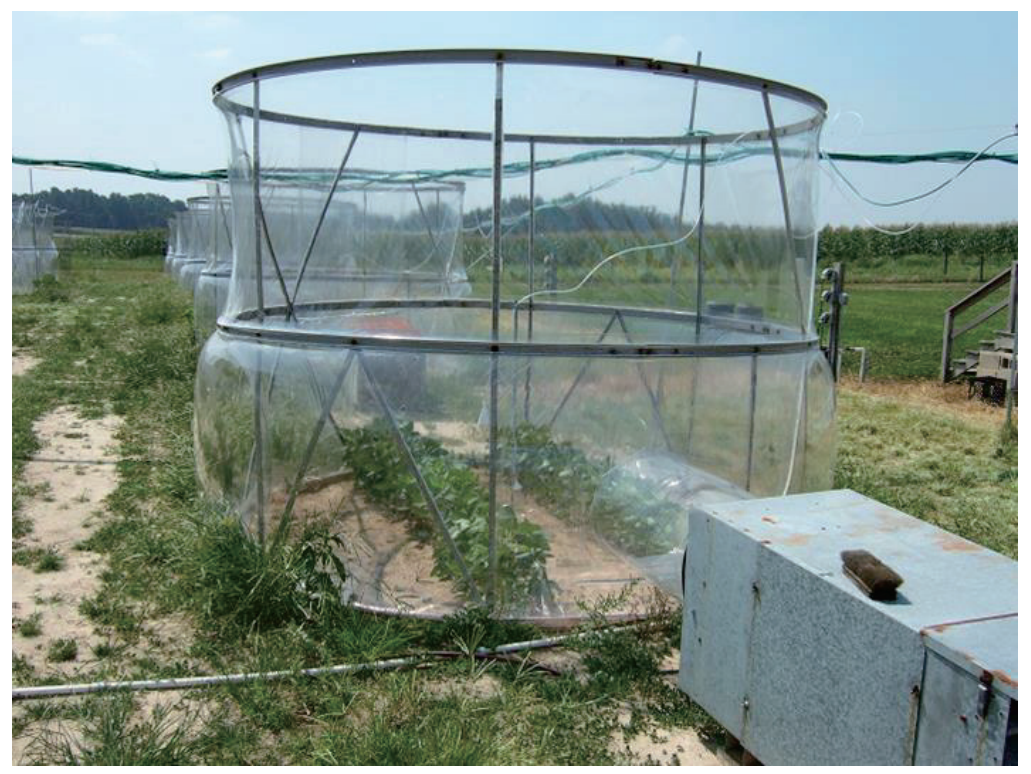

Fig. 2. An open-top chamber for exposing field crop species to ozone concentrations from sub-ambient to super-ambient levels in Raleigh, North Carolina, USA.



Fig. 3. A FACE-Ozone (free-air concentration elevation with ozone) apparatus for studying the ozone impacts on rice and wheat in Jiangdu, Jiangsu, China.

et al., 1973). The 'chamber effects' have been the issue of concern, since they could introduce a bias in the estimation of the $\mathrm{O}_{3}$ impacts using the dose-response relationships derived from the chamber experiments (Nussbaum and Fuhrer, 2000). If the chamber effects were to be accounted for entirely by the alteration to the $\mathrm{O}_{3}$ uptake rate in the plant leaves, the flux-based $\mathrm{O}_{3}$ dose (e.g. Pleijel et al., 2007) rather than the concentration-based one (e.g. Mills et al., 2007) could eliminate the bias in the estimates of the $\mathrm{O}_{3}$ impacts. Such an expectation has been questioned, however, by theoretical considerations (Kobayashi, 1996; Nussbaum and Fuhrer, 2000) and an observer's intuition (Kobayashi, 1999). It has been suggested that the dose-response relationships would change, as the plant growth changes due to the chamber effects
(Kobayashi, 1999). These concerns on the chamber effects had prompted the development of apparatus to raise the concentrations of air pollutants in the field without an enclosure (McLeod, 1995).

The concerns over the chamber effects were shared with those who had been trying to quantify the effects of elevated $\mathrm{CO}_{2}$ concentrations $\left(\left[\mathrm{CO}_{2}\right]\right)\left(\mathrm{e}\left[\mathrm{CO}_{2}\right]\right)$ on vegetation. It had been established by chamber experiments that plant photosynthesis is enhanced by the increase in $\left[\mathrm{CO}_{2}\right]$, and that plant growth and yield are thereby increased. The question at issue was whether such changes in the chambers will actually occur in the field under $\mathrm{e}\left[\mathrm{CO}_{2}\right]$ in the future.

The FACE (free-air $\mathrm{CO}_{2}$ enrichment) apparatus was designed to raise $\left[\mathrm{CO}_{2}\right]$ around the plant canopy in the field without any 
enclosures that disturb the canopy microclimate. The apparatus designed by the Brookhaven National Laboratory (BNL) in the USA showed for the first time that FACE can actually be used to the study of plant responses to $\left[\mathrm{CO}_{2}\right]$ (Allen et al, 1992). Since then, the BNL-type design has been adopted in FACE for various vegetation types including crops and forests (Kobayashi, 2001; Norby et al., 2001). Later on, however, it was found that the FACE apparatus altered the canopy microclimate and changed the plant phenology detectably (Pinter, Jr. et al., 2000). This artifact was caused by blowing a large volume of $\mathrm{CO}_{2}$-enriched air over the plant canopy. During night time inversion, the warmer air higher in the inversion was drawn down by the blower, and raised the canopy temperature. The blower effect was resolved by omitting the blower and injecting pure $\mathrm{CO}_{2}$ at a high pressure into the air surrounding the vegetation. The amount of blown air was drastically reduced, which eliminated the alteration to the canopy microclimate by the apparatus (Okada et al., 2001)

The FACE design with pressurized gas injection was adapted to FACE-Ozone (free-air concentration elevation with ozone) for soybean in the USA (Morgan et al., 2004) and subsequently for rice and wheat in China (Tang et al., 2011; Fig. 3). FACE-Ozone apparatus has been developed for forest trees also (Karnosky et al., 2007; Oksanen, 2003; Werner and Fabian, 2002).

\section{Contribution of FACE-Ozone to impact estimation and mechanism understandings.}

The development of FACE-Ozone apparatus has enabled the $\mathrm{O}_{3}$ exposure studies to be conducted in the field (Zhu et al., 2011), and thereby facilitated the dose-response relationships to be derived from the field experiments without the chamber effects (Feng et al., 2012). Using the dose-response relationships for wheat, the impact of rise in surface $\left[\mathrm{O}_{3}\right]$ was predicted for China and India, the world's largest and second-largest wheat producers (Tang et al., 2013). The prediction demonstrated the serious threat of rising surface $\left[\mathrm{O}_{3}\right]$ to wheat production in the near future.
FACE-Ozone also offers a unique opportunity for mechanism studies. Since the entire vegetation is subjected to elevated $\left[\mathrm{O}_{3}\right]$ $\left(\mathrm{e}\left[\mathrm{O}_{3}\right]\right)$ with the above- and below-ground environment kept intact, the plant process responses to $\mathrm{O}_{3}$ can be studied as a part of the whole ecosystem responses. This is particularly important for studying forest trees, whose size had often limited the $\mathrm{O}_{3}$ exposures to be conducted with small seedlings or only a part, e.g. branches, of an individual plant (Karnosky et al., 2007). With the FACE-Ozone apparatus, the scientists can now study the $\mathrm{O}_{3}$ impacts and the mechanisms of the responses to $\mathrm{e}\left[\mathrm{O}_{3}\right]$ with trees at greater ages than before.

\section{Articles in this issue.}

This issue is dedicated to the papers derived from the organized session: 'Sustainable forest and crop resources production affected by air pollution: Asian perspectives', which was held in association with the International Symposium on Agricultural Meteorology in 2014 in Sapporo, Hokkaido, Japan. This issue is characterized by, if not limited to, the reports of the findings on tree species in FACE-Ozone (Fig. 4).

\subsection{Findings in FACE and FACE-Ozone.}

Koike et al. (2015) reviewed the ecophysiological responses of deciduous trees in Northeast Asia to $\left[\mathrm{CO}_{2}\right]$ in the FACE experiments. They stressed the importance of studying the whole-plant physiology under $\mathrm{e}\left[\mathrm{CO}_{2}\right]$ for better understanding the mechanisms of the plant responses to $\left[\mathrm{CO}_{2}\right]$. As mentioned above, FACE offers a unique opportunity for the study on the entire plant under $\mathrm{e}\left[\mathrm{CO}_{2}\right]$. Watanabe et al. (2015) reported the responses of leaf photosynthesis in saplings of Japanese oak to e $\left[\mathrm{O}_{3}\right]$. In the FACEOzone, the saplings grew within a canopy rather than as spatiallyseparated individual plants enabling the authors to compare between upper and lower canopy leaves under e $\left[\mathrm{O}_{3}\right]$. The photosynthetic responses to $\mathrm{e}\left[\mathrm{O}_{3}\right]$ were similar between the leaves in different canopy positions as opposed to their own findings in the past with Siebold's beech, in which upper-canopy leaves were

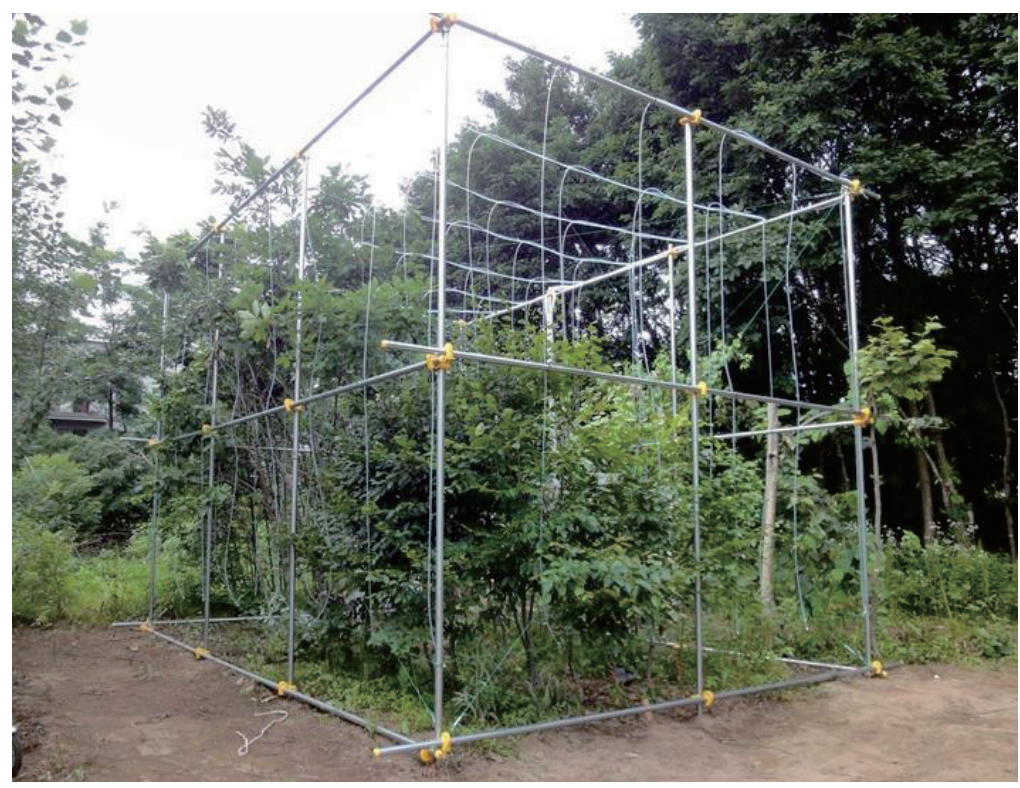

Fig. 4. A FACE-Ozone apparatus for studying the ozone impacts on tree species in Sapporo, Hokkaido, Japan. 
more sensitive to $\left[\mathrm{O}_{3}\right]$ than the lower-canopy ones.

In FACE-Ozone, the effects of $\mathrm{e}\left[\mathrm{O}_{3}\right]$ on plants can be studied in combination with the effects of other anthropogenic changes. Kam et al. (2015) studied the $\mathrm{O}_{3}$ impacts in interaction with the increased nitrogen loading on growth of Japanese larch and its hybrid. They found that the plants grown with increased nitrogen loading were less sensitive to $\left[\mathrm{O}_{3}\right]$. The effects of nitrogen loading per se were studied by Ji et al. (2015), who focused on the responses of needle morphology and photosynthetic proteins in Japanese larch to shading treatment. Their findings indicated that seedlings of Japanese larch under shade of large trees store the extra nitrogen from increased loadings into photosynthetic proteins to prepare for a chance of increased insolation due to a gap opening.

\subsection{Modeling the ozone impacts on leaf gas exchange.}

The impacts of $\mathrm{e}\left[\mathrm{O}_{3}\right]$ on vegetation are better described by fluxbased than concentration-based $\mathrm{O}_{3}$ doses (Pleijel et al., 2007; Mills et al., 2011). Since the $\mathrm{O}_{3}$ uptake by vegetation is predominantly via the leaf stomata, and stomata usually close in response to $\mathrm{e}\left[\mathrm{O}_{3}\right]$, modeling of stomatal conductance under $\mathrm{e}\left[\mathrm{O}_{3}\right]$ is critical for a better impact estimation. The findings by Hoshika et al. (2015a) and Hoshika et al. (2015b) with Siebold's beech are important in that the stomatal closure in response to $\mathrm{e}\left[\mathrm{O}_{3}\right]$ was lost after $\mathrm{O}_{3}$ exposure in the late growing season. Their results appear to be at odds with the results for other species, e.g. rice (Oue et al., 2008) and wheat (Grueters et al., 1995; Oue et al., 2009), due presumably to the differences in species studied and approaches to the analyses. When the flux-based $\mathrm{O}_{3}$ doses are related with the impacts on vegetation, a non-zero threshold value is usually assumed for a better fit to the observed plant responses. Yamaguchi et al. (2015) went on by one step further into the mechanisms of the threshold by studying the photosynthetic responses to $\mathrm{e}\left[\mathrm{O}_{3}\right]$ and anti-oxidative enzyme activities in rice flag leaves in a chamber experiment. Their findings are interesting in that the $\mathrm{O}_{3}$ uptake rate was reduced later in the leaf lifespan, whereas the antioxidant activities were also diminished at the later leaf ages. The net impact of $\mathrm{e}\left[\mathrm{O}_{3}\right]$ on leaf photosynthesis might therefore be greater than that estimated by the stomatal uptake dose exceeding a fixed threshold value.

\subsection{Characterizing the air pollution in the real-world field.}

A good characterization of the air pollution in the real-world fields is the premise for the accurate estimation of the air pollution impacts on vegetation using a model of the impacts. Ozone concentrations at three forest sites in Japan were analyzed with respect to the calculated $\mathrm{O}_{3}$ risks for vegetation (Komatsu et al., 2015). The two forests with sensitive species being dominant appear to be at risk of $\mathrm{O}_{3}$ damages. In addition to $\mathrm{O}_{3}$, deposition of aerosols (Watanabe, 2015) and nitrate- and sulfate-ions (Yamaguchi and Noguchi, 2015) were also addressed for their potential impacts on vegetation.

\subsection{A chemical alternative to FACE-Ozone?}

Agathokleous et al. (2015) reviewed the use of Ethylene-diurea (EDU) for the $\mathrm{O}_{3}$ impact research. EDU can protect plants from $\mathrm{O}_{3}$ damages, when it is applied with an appropriate method and at the optimal dose. Mode of the action of EDU in plants has not been fully understood yet, however. Because of this, EDU would not be the first choice of research tool for the mechanism studies, where the major interest is in the mechanisms of $\mathrm{O}_{3}$ rather than EDU, and they would prefer not to worry about the yet-to-beunderstood mechanisms of EDU.

As a research tool for quantifying the $\mathrm{O}_{3}$ impacts, in contrast, EDU has a clear advantage: the plants grow in the field without enclosures and no (or little) $\mathrm{O}_{3}$ impacts. The plant performance in ambient field as compared with that in EDU-treated field would show the impacts of current $\left[\mathrm{O}_{3}\right]$. FACE-Ozone, by comparison, cannot reduce the $\left[\mathrm{O}_{3}\right]$ in the field, and, hence, can only show the impacts of increased $\left[\mathrm{O}_{3}\right]$. EDU could therefore complement rather than replace FACE-Ozone by realizing a field with no or reduced $\mathrm{O}_{3}$ impacts without a chamber. To this end, it would be crucial to establish the dose and application methods of EDU to protect the plants effectively without any 'side effects' (Agathokleous et al., 2015), which refers to the effects of EDU on plants at zero $\mathrm{O}_{3}$ dose.

\section{Attaining the goal of scientific studies on air pollution impacts.}

An ultimate goal of the air pollution impact studies would be to prevent the air pollution damages from reaching an unacceptable level. The improved quantification of the air pollution impacts should facilitate the preventive or remedial actions against the impacts by giving scientifically sound estimates of the efficacy of such actions. The mechanisms studies could facilitate the better quantifications of the air pollution impacts as well as the development of counter-measures against them. FACE-Ozone serves as a platform for the scientists to work on both mechanisms and quantification of surface $\mathrm{O}_{3}$ impacts on vegetation as mentioned earlier. The articles in this issue demonstrate the phenomenal progresses made by the Asian scientists with FACE-Ozone and other approaches. I must, however, note that the goal is also moving fast as the surface $\left[\mathrm{O}_{3}\right]$ is rising rapidly in many areas of Asian countries due to the increasing emission of nitrogen oxides (NOx), a major precursor of tropospheric $\mathrm{O}_{3}$. Asia as a region had become the world's largest NOx emitter in late 1990s having exceeded the emissions from North America and Europe, where NOx emission had mostly been stabilized (Akimoto, 2003). I sincerely hope that the efforts of the scientists and those in charge of air quality management would make progresses faster enough to reach the ultimate goal for Asia.

\section{References}

Agathokleous, E., Koike, T., Watanabe, M., Hoshika, Y., and Saitanis, C. J., 2015: Ethylene-di-urea (EDU), an effective phytoprotectant against $\mathrm{O}_{3}$ deleterious effects and a valuable research tool. Journal of Agricultural Meteorology, 71, 185-195.

Akimoto, H., 2003: Global air quality and pollution. Science, 302, 1716-1719.

Allen, Jr., L. H., Drake, B. G., Rogers, H. H., and Shinn, J. H., 1992: Field techniques for exposure of plants and ecosystems to elevated $\mathrm{CO}_{2}$ and other trace gases. Critical Reviews in Plant Sciences, 11, 85-119.

Ashmore, M. R., 2005: Assessing the future global impacts of ozone on vegetation. Plant, Cell and Environment, 28, 949-964.

Avnery, S., Mauzerall, D. L., Liu, J., and Horowitz, L. W., 2011a: Global crop yield reductions due to surface ozone exposure: 1 . Year 2000 crop production losses and economic damage. At- 
mospheric Environment, 45, 2284-2296.

Avnery, S., Mauzerall, D. L., Liu, J., and Horowitz, L. W., 2011b: Global crop yield reductions due to surface ozone exposure: 2 Year 2030 potential crop production losses and economic damage under two scenarios of $\mathrm{O}_{3}$ pollution. Atmospheric Environment, 45, 2297-2309.

Feng, Z., and Kobayashi, K., 2009: Assessing the impacts of current and future concentrations of surface ozone on crop yield with meta-analysis. Atmospheric Environment, 43, 1510-1519.

Feng, Z., Sun, J., Wan, W., Hu, E., and Calatayud, V., 2014: Evidence of widespread ozone-induced visible injury on plants in Beijing, China. Environmental Pollution, 193, 296-301.

Feng, Z., Tang, H., Uddling, J., Pleijel, H., Kobayashi, K., Zhu, J., Oue, H., and Guo, W., 2012: A stomatal ozone flux-response relationship to assess ozone-induced yield loss of winter wheat in subtropical China. Environmental Pollution, 164, 16-23.

Grueters, U., Fangmeier, A., and Jaeger, H.-J., 1995: Modelling stomatal responses of spring wheat (Triticum aestivum L. cv. Turbo) to ozone at different levels of water supply. Environmental Pollution, 87, 141-149.

Heagle, A. S., Body, D. E., and Heck, W. W., 1973: An open-top field chamber to assess the impact of air pollution on plants. Journal of Environmental Quality, 2, 365-368.

Heggestad, H. E., and Middleton, J. T., 1959: Ozone in high concentrations as cause of tobacco leaf injury. Science, 129, 208 210.

Hoshika, Y., Katata, G., Deushi, M., Watanabe, M., Koike, T., and Paoletti, E., 2015a: Ozone-induced stomatal sluggishness changes carbon and water balance of temperate deciduous forests. Scientific Reports, 5, 9871, 1-8.

Hoshika, Y., Watanabe, M., Inada, N., and Koike, T., 2015b: Effects of ozone-induced stomatal closure on ozone uptake and its changes due to leaf age in sun and shade leaves of Siebold's beech. Journal of Agricultural Meteorology, 71, 218-226.

Ji, D.-H., Mao, Q., Watanabe, Y., Kitao, M., and Kitaoka, S., 2015: Effect of nitrogen loading on the growth and photosynthetic responses of Japanese larch seedlings grown under different light regimes. Journal of Agricultural Meteorology, 71, 232-238.

Kam, D.-G., Shi, C., Watanabe, M., Kita, K., Satoh, F., and Koike, T. 2015: Growth of Japanese and hybrid larch seedlings grown under free-air $\mathrm{O}_{3}$ fumigation -an initial assessment of the effects of adequate and excessive nitrogen. Journal of Agricultural Meteorology, 71, 239-244.

Karnosky, D. F., Skelly, J. M., Percy, K. E., and Chappelka, A. H. 2007: Perspectives regarding 50 years of research on effects of tropospheric ozone air pollution on US forests. Environmental Pollution, 147, 489-506.

Kobayashi, K., 1996: Variation in the relationship between ozone exposure and crop yield as derived from simple models of crop growth and ozone impact. Atmospheric Environment, 31, 703714.

Kobayashi, K., 1999: Assessing the impacts of tropospheric ozone on agricultural production. Journal of Japan Society for Atmospheric Environment, 34, 162-175. (in Japanese with English summary)

Kobayashi, K., 2001: FACE (free-air $\mathrm{CO}_{2}$ enrichment) experiment. Japanese Journal of Crop Science, 70, 1-16. (in Japanese)

Koike, T., Watanabe, M., Watanabe, Y., Agathokleous, E., Eguchi, N., Takagi, K., Satoh, F., Kitaoka, S., and Funada, R., 2015: Ecophysiology of deciduous trees native to Northeast Asia grown under FACE (Free Air $\mathrm{CO}_{2}$ Enrichment). Journal of Agricultural Meteorology, 71, 174-184.

Komatsu, M., Yoshimura, K., Fujii, S., Yazaki, K., Tobita, H., Mizoguchi, Y., Miyama, T., Kominami, Y., Yasuda, Y., Yamanoi, K., and Kitao, M., 2015: Estimation of ozone concentrations above forests using atmospheric observations at urban air pollution monitoring stations. Journal of Agricultural Meteorology, 71, 202-210.

Matsuoka, Y., Takasaki, T., Morikawa, M., Matsumaru, T., and Shiratori, K., 1976: Studies on the visible injury to rice plants caused by photochemical oxidants: I. Identification of the leaf injury caused by photochemical oxidants. Proceedings of the Crop Science Society of Japan, 45, 124-130. (in Japanese with English summary)

McLeod, A. R., 1995: An open-air system for exposure of young forest trees to sulphur dioxide and ozone. Plant, Cell and Environment, 18, 215-225.

Mills, G., Buse, A., Gimeno, B., Bermejo, V., Holland, M., Emberson, L., and Pleijel, H., 2007: A synthesis of AOT40-based response functions and critical levels of ozone for agricultural and horticultural crops. Atmospheric Environment, 41, 2630 2643.

Mills, G., Hayes, F., Simpson, D., Emberson, L., Norris, D., Harmens, H., and Bueker, P., 2011: Evidence of widespread effects of ozone on crops and (semi-) natural vegetation in Europe (1990-2006) in relation to AOT40- and flux-based risk maps. Global Change Biology, 17, 592-613.

Morgan, P. B., Bernacchi, C. J., Ort, D. R., and Long, S. P., 2004: An in vivo analysis of the effect of season-long open-air elevation of ozone to anticipated 2050-levels on photosynthesis in soybean. Plant Physiology, 135, 2348-2357.

Norby, R. J., Kobayashi, K., and Kimball, B. A., 2001: Rising $\mathrm{CO}_{2}$-future ecosystems. New Phytologist, 150, 215-221.

Nussbaum, S., and Fuhrer, J., 2000: Difference in ozone uptake in grassland species between open-top chambers and ambient air. Environmental Pollution, 109, 463-471.

Okada, M., Lieffering, M., Nakamura, H., Yoshimoto, M., Kim, H. Y., and Kobayashi, K., 2001: Free-air $\mathrm{CO}_{2}$ enrichment (FACE) using pure $\mathrm{CO}_{2}$ injection: system description. New Phytologist, 150, 251-260.

Oksanen, E., 2003: Responses of selected birch (Betula pendula Roth) clones to ozone change over time. Plant, Cell and Environment, 26, 875-886.

Oue, H., Feng, Z., Pang, J., Miyata, A., Mano, M., Kobayashi, K., and $\mathrm{Zhu}$, J., 2009: Modeling the stomatal conductance and photosynthesis of a flag leaf of wheat under elevated $\mathrm{O}_{3}$ concentration. Journal of Agricultural Meteorology, 65, 239-248.

Oue, H., Motohiro, S., Inada, K., Miyata, A., Mano, M., Kobayashi, K., and Zhu, J., 2008: Evaluation of ozone uptake by the rice canopy with the multi-layer model. Journal of Agricultural Meteorology, 64, 223-232.

Pinter, Jr., P. J., Kimball, B. A., Wall, G. W., LaMorte R. L., Hunsaker, D. J., Adamsen, F. J., Frumau, K. F. A., Vugts, H. F., Hendrey, G. R., Lewin, K. F., Nagy, J., Johnson, H. B., Wechsung, F., Leavitt, S. W., Thompson, T. L., Matthias, A. D., and Brooks. T. J., 2000: Free-air $\mathrm{CO}_{2}$ enrichment (FACE): blower effects on wheat canopy microclimate and plant development. Agricultural and Forest Meteorology, 103, 319-333.

Pleijel, H., Danielsson, H., Emberson, L., Ashmore, M. R., and Mills, G., 2007: Ozone risk assessment for agricultural crops in Europe: Further development of stomatal flux and fluxresponse relationships for European wheat and potato. Atmos- 
pheric Environment, 41, 3022-3040.

Richards, B. L., Middleton, J. T., and Hewitt, W. B., 1958: Air pollution with relation to agronomic crops. V. Oxidant stipple of grape. Agronomy Journal, 50, 559-561.

Tang, H., Liu, G., Han, Y., Zhu, J., and Kobayashi, K., 2011: A system for free-air ozone concentration elevation with rice and wheat: control performance and ozone exposure regime. Atmospheric Environment, 45, 6276-6282.

Tang, H., Takigawa, M., Liu, G., Zhu, J., and Kobayashi, K., 2013: A projection of ozone-induced wheat production loss in China and India for the years 2000 and 2020 with exposurebased and flux-based approaches. Global Change Biology, 19, 2739-2752.

The Royal Society, 2008: Ground-level ozone in the 21st century: future trends, impacts and policy implications. Science Policy Report 15/08.

https://royalsociety.org/policy/publications/2008/ground-level-ozone/

Watanabe, Y., 2015: Canopy, leaf surface structure and tree phenology: Arboreal factors influencing aerosol deposition in forests. Journal of Agricultural Meteorology, 71, 167-173.
Watanabe, M., Hoshika, Y., Inada, N., and Koike, T., 2015: Difference in photosynthetic responses to free air ozone fumigation between upper and lower canopy leaves of Japanese oak (Quercus mongolica var. crispula) saplings. Journal of Agricultural Meteorology, 71, 227-231.

Werner, H., and Fabian, P., 2002: Free-air fumigation of mature trees. A novel system for controlled ozone enrichment in grown-up beech and spruce canopies. Environmental Science and Pollution Research, 9, 117-121.

Yamaguchi, T., and Noguchi, I., 2015: Long-term trends for nitrate and sulfate ions in snowcover on Hokkaido, northern Japan. Journal of Agricultural Meteorology, 71, 196-201.

Yamaguchi, M., Hoshino, D., Kondo, T., Satoh, R., Inada, H., and Izuta, T., 2015: Evaluation of $\mathrm{O}_{3}$ effect on net photosynthetic rate in flag leaves of rice (Oryza sativa L.) by stomatal $\mathrm{O}_{3}$ flux and radical scavenging enzyme activities. Journal of Agricultural Meteorology, 71, 211-217.

Zhu, X., Feng, Z., Sun, T., Liu, X., Tang, H., Zhu, J., Guo, W., and Kobayashi, K., 2011: Effects of elevated ozone concentration on yield of four Chinese cultivars of winter wheat under fully open-air field conditions. Global Change Biology, 17, 2697-2706. 